\title{
IPRs, Technological Development, and Economic Development
}

\author{
Wilfred Dolfsma
}

\begin{tabular}{|l|l|}
\hline \multicolumn{2}{|l|}{ ERIM REPORT SERIES RESEARCH IN MANAGEMENT } \\
\hline ERIM Report Series reference number & ERS-2006-004-ORG \\
\hline Publication & January 2006 \\
\hline Number of pages & 11 \\
\hline Persistent paper URL & \\
\hline Email address corresponding author & wdolfsma@rsm.nl \\
\hline Address & Erasmus Research Institute of Management (ERIM) \\
& RSM Erasmus University / Erasmus School of Economics \\
& Erasmus Universiteit Rotterdam \\
& P.O.Box 1738 \\
& 3000 DR Rotterdam, The Netherlands \\
& Phone: $\quad+31104081182$ \\
& Fax: $\quad+31104089640$ \\
& Email: info@erim.eur.nl \\
& Internet: $\quad$ www.erim.eur.nl \\
\hline
\end{tabular}

Bibliographic data and classifications of all the ERIM reports are also available on the ERIM website: www.erim.eur.nl 


\begin{tabular}{|c|c|}
\hline \multicolumn{2}{|c|}{ ABSTRACT AND KEYWORDS } \\
\hline Abstract & 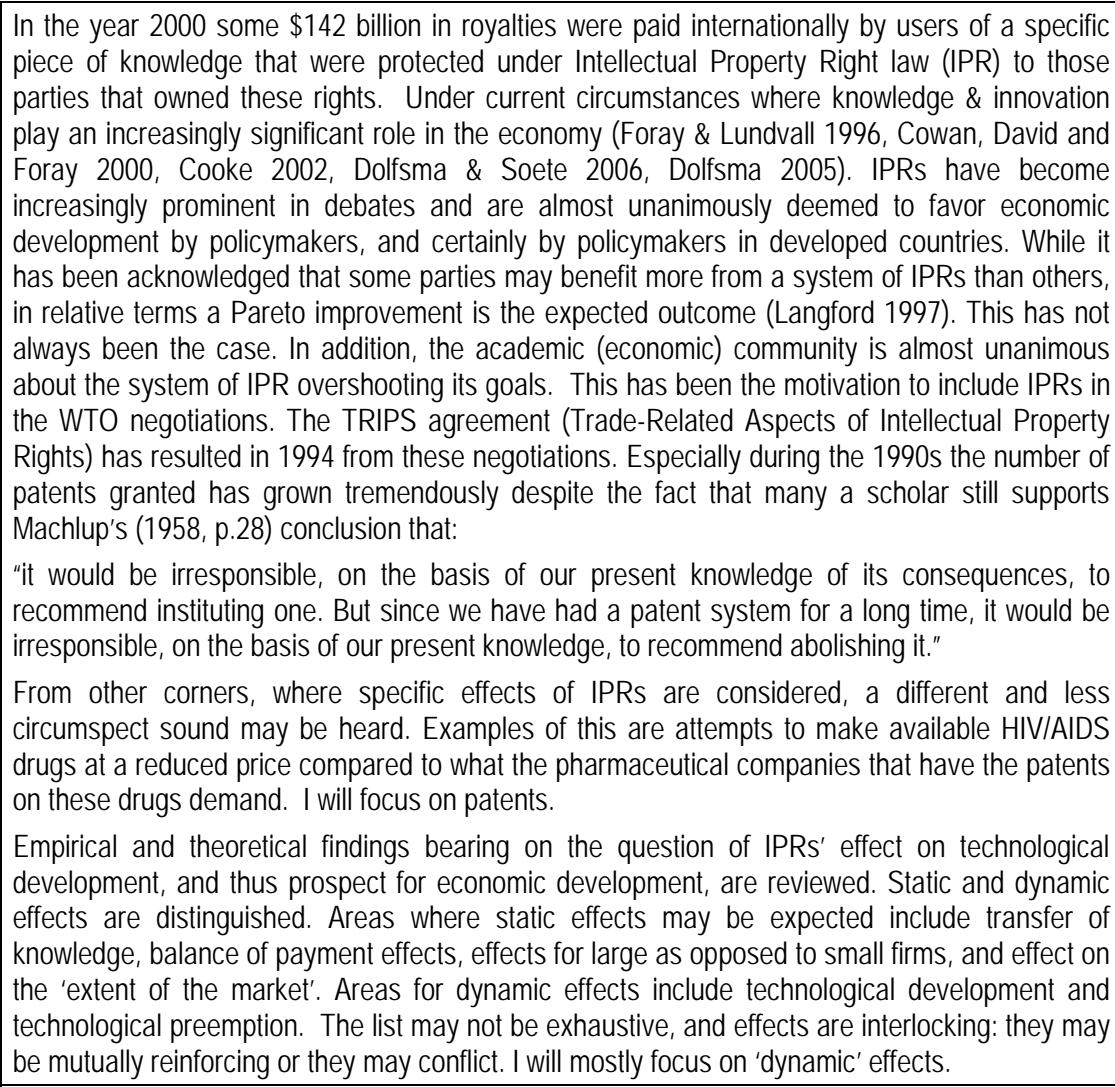 \\
\hline Free Keywords & Intellectual Property Rights, IPRs, Technological Development, Economic Dynamics \\
\hline Availability & $\begin{array}{l}\text { The ERIM Report Series is distributed through the following platforms: } \\
\text { Academic Repository at Erasmus University (DEAR), DEAR ERIM Series Portal } \\
\text { Social Science Research Network (SSRN), SSRN ERIM Series Webpage } \\
\text { Research Papers in Economics (REPEC), REPEC ERIM Series Webpage }\end{array}$ \\
\hline Classifications & $\begin{array}{l}\text { The electronic versions of the papers in the ERIM report Series contain bibliographic metadata } \\
\text { by the following classification systems: } \\
\text { Library of Congress Classification, (LCC) } \underline{\text { LCC Webpage }} \\
\text { Journal of Economic Literature, (JEL), JEL Webpage } \\
\text { ACM Computing Classification System CCS Webpage } \\
\text { Inspec Classification scheme (ICS), ICS Webpage }\end{array}$ \\
\hline
\end{tabular}




\title{
IPRs, Technological Development, and Economic Development ${ }^{1}$
}

\author{
"Since it is rooted in a contradiction, there can be no such thing as \\ an ideally beneficial patent system, and it is bound to produce \\ negative results in particular instances” - Joan Robinson \\ "[O]wnership ... gives the owner not only the right of use \\ over the community's immaterial equipment, but also the right \\ of abuse and of neglect and inhibition” - Thorstein Veblen
}

Wilfred Dolfsma ${ }^{2}$

In the year 2000 some $\$ 142$ billion in royalties were paid internationally by users of a specific piece of knowledge that were protected under Intellectual Property Right law (IPR) to those parties that owned these rights. ${ }^{i}$ Under current circumstances where knowledge \& innovation play an increasingly significant role in the economy (Foray \& Lundvall 1996, Cowan, David and Foray 2000, Cooke 2002, Dolfsma \& Soete 2006, Dolfsma 2005). IPRs have become increasingly prominent in debates and are almost unanimously deemed to favor economic development by policymakers, and certainly by policymakers in developed countries. While it has been acknowledged that some parties may benefit more from a system of IPRs than others, in relative terms a Pareto improvement is the expected outcome (Langford 1997). This has not always been the case. In addition, the academic (economic) community is almost unanimous about the system of IPR overshooting its goals. ${ }^{\text {ii }}$ This has been the motivation to include IPRs in the WTO negotiations. The TRIPS agreement (TradeRelated Aspects of Intellectual Property Rights) has resulted in 1994 from these negotiations. Especially during the 1990s the number of patents granted has grown tremendously despite the fact that many a scholar still supports Machlup’s (1958, p.28) conclusion that:

\footnotetext{
${ }^{1}$ This paper was presented at the World Summit on the Information Society, Tunis, November 13-19, 2005 as well as at the 2006 annual Association for Evolutionary Economics meetings, Boston, MA, January 5-8. I would like to thank participants of these sessions, and especially Robert Loube.

${ }^{2}$ Erasmus University Rotterdam, Maastricht University (MERIT), and 2005/6 NIAS Fellow. Correspondence: Erasmus University Rotterdam, FBK, PO Box 1738, NL-3000 DR Rotterdam, the Netherlands, wdolfsma@rsm.nl
} 
"it would be irresponsible, on the basis of our present knowledge of its consequences, to recommend instituting one. But since we have had a patent system for a long time, it would be irresponsible, on the basis of our present knowledge, to recommend abolishing it.”

From other corners, where specific effects of IPRs are considered, a different and less circumspect sound may be heard. Examples of this are attempts to make available HIV/AIDS drugs at a reduced price compared to what the pharmaceutical companies that have the patents on these drugs demand. ${ }^{\mathrm{iii}}$ I will focus on patents.

Empirical and theoretical findings bearing on the question of IPRs' effect on technological development, and thus prospect for economic development, are reviewed. Static and dynamic effects are distinguished. Areas where static effects may be expected include transfer of knowledge, balance of payment effects, effects for large as opposed to small firms, and effect on the 'extent of the market'. Areas for dynamic effects include technological development and technological preemption. ${ }^{\text {iv }}$ The list may not be exhaustive, and effects are interlocking: they may be mutually reinforcing or they may conflict. I will mostly focus on 'dynamic' effects.

\section{Intellectual Property Rights}

Intellectual objects are non-exclusive: consumption or use by non-payers cannot be excluded. In addition, intellectual objects are partly non-rivalrous as well: they are not consumed by their use. This makes intellectual objects (quasi-)public goods, giving governments a reason to influence relevant processes in society. As costs of imitating or communicating intellectual objects tend to be low, there may be a tendency for these to be under-produced (Nelson 1959, Romer 2002). IPRs would provide a way to compensate creative individuals that is saving on transactions costs by stipulating that the commercial use of knowledge is exclusive to the right-holder. Discussion of the need for society of IPRs has waxed and waned (Towse \& Holzhauer 2002). Notwithstanding such discussions, the scope and duration of IPRs has increased steadily over time.

Rationales for IPRs fall into four, partly related categories (Hettinger 1989). The extent to which rationales are stressed in law differs between countries, reflected in the authority that administers them. In the UK and the US, the incentive for creative individuals or organizations that IPRs offer is emphasized: development and diffusion of new knowledge is promoted by the prospect of a period of time in which one is able to commercially exploit the innovation. ${ }^{\mathrm{v}}$ Relatedly, IPRs are said to be necessary for firms to entice them to invest in facilities for the production of goods based on the intellectual object protected under IPR. Without it, firms would face more than the usual business risk and refrain from the production of such goods. In the UK and the US, these are the rationales 
emphasized, and this is reflected in the fact that the Commerce Department administers such rights. The two other rationales are not related to such utilitarian considerations and are specifically emphasized in the legal systems of continental Europe (and those based on or influenced by them). The first is one of desert. If someone has produced an intellectual object, she deserves some kind and measure of reward. The final rationale is personal/moral one. In creating an intellectual object, someone expresses one’s personality. ${ }^{\mathrm{vi}}$

Over time, the first and second rationales have become increasingly dominant in the discussions. Philosopher John Locke's argument in his Second Treatise of Civil Government (1690) for a 'natural' property right in what one makes has a strong intuitive appeal. In reality, however, it is a government that creates and polices IPRs; they are a socially created privilege. Intellectual objects differ from physical ones. In their creation, for instance, one draws on work done (by others) in the past; creation is not de novo. When use of existing work is restricted, society may be hurt. As intellectual objects are public goods, granting a (temporary) monopoly on their commercial exploitation may not leave 'enough and as good' vii Independent inventors are hurt as they may be prohibited from using something they have developed themselves but another party was granted a patent for earlier. It is further argued that intellectual objects are more often than physical ones the result of cooperation - a cooperation that may or may not be promoted by IPRs (Dolfsma 2007).

This paper does not call into question the need for a system of IPR per se, yet it does elaborate on criticisms of it for possible hampering of future economic development even for developed economies (Dolfsma 2005). The IPR system also presents immanent problems, especially for developing countries. The immanent problems referred to relate to the consequences of the system of IPRs for the distribution of national incomes within and among countries. In order to reap the benefits believed to result from joining consecutive rounds of negotiations to liberalize international trade, developing countries have had to accept WTO standards for IPRs.

\section{The Patent Practice}

While one may quarrel about the theory that support a system of IPRs in general and patents in particular, there is also the practice of filing, evaluating and granting. This practice differs between countries, with effects for the firms involved (OECD 1997). While most countries maintain a 'first-tofile' policy, the US maintains a 'first-to-invent' policy. This difference has major consequences for strategic behavior of firms seeking patents under the different regimes. Another difference is between the scope of the claim staked in a patent. In Japan, for instance, the claim must be much more narrowly defined than in the US. A broad claim in a patent is a stronger claim in a preemptive action than a narrow claim is. There are also features about patent system in general that have been 
lamented. Some point to the granting of patents that obviously do not meet the criteria for patents: patents have been given for technology that had already been developed, for technology that had no industrial application or physical component, \&c. Others, in contrast, point to the losses in terms of forgone license payments due to poor IPR law and/or poor protection.

The expansion in both scope and length has been criticized for representing 'a new stage in commodification', 'corrupting society’ ‘destructing productivity’ (Perelman 2003). In recent years plant variety rights have been strengthened, business models and software have come to be protected under patent law. The number of patent applications have risen by an annual 6\% since 1990 to total 350 thousand a year; 190,000 are awarded, half of which to non-US firms. ${ }^{\text {viii }}$ In 2003, a backlog of half-a-million applications was reported. The US Patent Office is now receiving its income from parties that have been awarded a patent - no incentive to diligently search for 'prior art' and determine whether an application meets the criteria. The burden of proof seems to be on the side of the USPTO to proof that a patent application is not to be granted. Indeed, half of all patents that were apparently important enough to litigated were found to be invalid. Only $23 \%$ of new drugs developed provide therapeutic benefit over existing drugs (Hubbard \& Love 2004) - a notable figure for an industry that relies heavily on patents (Levin et al. 1987, Arundel 2001). A mere 1\% is spent on 'neglected diseases.'

Baumol (2002) has estimated that twenty percent of the benefits associated with an invention are appropriated by the parties directly or indirectly involved with the invention. Only partly will the appropriation of benefits be due to IPRs. Patents offer no certainty of appropriating market rents. Many will not have economic value; increasing numbers have very little technical value. Of all US patents granted, 55-75 percent lapse for failure to pay maintenance fees; if litigation against a patent's validity is a sign of commercial value of that patent, the fact that only $1.5 \%$ of patents are litigated and only 0.1 percent litigated to trial does not bode well (Lemley \& Shapiro 2005).

'Even' mainstream economic literature has argued at length and in great detail the drawbacks and pitfalls of current IPR law, and developments therein. Let me discuss the most important findings.

\section{Static Effects of IPRs}

It is becoming increasingly difficult for developing countries to ignore IPR policies. Only when a country has a sufficiently attractive internal market and/or has a sufficiently strong research tradition itself will it be able to negotiate on an equal footing. China, India and Brazil are examples of countries that are able to credibly use the threat of drawing on the compulsory license clause in TRIPS to make right holders lower the price of the products they offer. Particularly if the product and 
its uses can draw a lot of attention in the media - such as in case of HIV/AIDS medication - such an approach may be successful.

If a country offers protection of IPRs that is perceived as too weak, FDI might suffer and exports of products that embody new technology might be lower to for fear of such products being reimported. Although not in the spirit of the WTO, parallel imports of IPR or products embodying protected rights are forbidden, thus setting boundaries to the 'extent of the market'. In legal terms, IPRs exhaust nationally not internationally. This has the effect of driving up market prices, obviously, as market structure and competitive relations are affected (Klaes 1987). Alternatives to any product may exist that draw on technology that is not patented, or that a second firm owns the patent for. Demand elasticity and pricing regulations are other elements that might affect prices. Administrative price ceilings - allowed under TRIPS - are a common strategy of developing countries. These may not prompt foreign patent-owning firms to supply countries that have such measures in the first place. As ceilings tend to be based on a cost-plus formula, there is an incentive for supplying firms to inflate transfer prices. A ceiling in any particular (developed) country might also be indexed to prices in other (developing) markets. There is thus an incentive to negotiate high prices in index-countries such as India.

\section{Dynamic Effects of IPRs}

Patents may raise incentives for R\&D in neglected areas of technology. Yet, it may not lead to such investments, and might thus be said to have perverse effects. This section looks at such perverse effects on technological development and future possibilities for economic growth (Dolfsma 2005).

Overly stringent protection might lead to more resources being devoted to IP management (Langford 1997): technology transfer cost may well increase. Overly stringent protection offered by patents (and other IPRs) may also lead to wasteful research spending such as patent races and the construction of patent portfolios. Levin et al. (1987) and Arundel (2001) have found that patents are not seen by firms as the most important way to appropriate the benefits of their innovative efforts: secrecy, lead time and complementary capabilities are. Certainly this holds for smaller firms. In a classical study Mansfield (1986) suggests that in most industries firms seek patent mostly for strategic reasons.

Having a patent can lead a firm to delay products based on it, as competing firms may not be able to offer alternatives (Takalo \& Kanniainen 2000). Although the monopoly awarded by a patent or any kind of IPR is never perfect, it may well induce a firm to consciously forgo the development of a new technology that would be socially more desirable - it may for instance develop a technologically inferior technology that yields it higher profits (Adams \& Encaoua 1994). Another 
dynamic effect may be that research effort may shift from areas where IPRs are less extensive and not as strictly enforced to areas where they are (Langford 1997). Firms are deterred from trying to invent 'in the neighborhood' of patents granted previously, including from undertaking follow-up inventive work (Mazzoleni \& Nelson 1998; Scotchmer \& Green 1990). This holds particularly where the technology involved is 'complex' and its development cumulative: much research as well as development is highly cumulative in nature. ${ }^{\mathrm{ix}}$ In a patent race an incumbent might want to maintain its position by preempting entry rather than developing technology (Harris \& Vickers 1985). If an incumbent does obtain a patent it may not be a valuable one in an economic or a technical sense (Gilbert \& Newbery 1982).

For complex technologies whose development is highly cumulative, where economies of scale are substantial, and given additional means to appropriate the benefits of innovation, the extent to which agents in developing countries can imitate is limited, whether they would like to imitate or not. In such cases, a tightening of IPR will actually hurt the developed countries as product lines will shift to or remain in these countries (Helpman 1993). Costs advantages of production in developing, assuming such advantages would benefit consumers, would favor the developed countries. A tighter IPR regime in case of a slow imitation pace hurts developed countries in general, even though it may benefit producers of the goods involved. When imitation rates are high, a tighter IPR regime will benefit developed countries but certainly not developing countries - it is under these circumstances that the general interest of the two groups of countries conflict. ${ }^{\mathrm{x}}$

Pooling of patents may be efficient, but it certainly also constitutes an entry barrier and is disadvantageous for smaller firms (Lanjouw \& Schankermann 2004). ${ }^{\text {xi }}$ Litigation costs can be so inhibitive that individual and small firm patent holders strike a deal with a large firm that filed a suit even when on legal grounds they would have a strong case; listed firms have lower filing rates (ibid.). Small firms have been found not to pursue innovative paths where the threat of a law suit by a larger firm is high (Lerner 1995). Rent seeking may thus have an effect not just on the application of new technology, but on the kind of new technology that firms seek to develop.

Certainly, then, there is a tension, in general, between anti-trust law and IP law.

Surely, too, there is a possible tension between IPR and development, especially in the early phases of economic development.

\section{Concluding remarks}

Developed countries stand to gain most from liberalizing the trade in IPRs with protection levels and scopes determined as they are in these countries, specifically in industries where imitation can be 
rapid and thus the benefits of diffusion are substantial. Mazzoleni \& Nelson (1998) argue that the US has pushed TRIPS most adamantly, attributing its zeal to self-interest as well as an 'honest believe'.

That zeal has not always been there. The US and other countries that now have developed economies have been haphazard in implementing and enforcing IPRs when they were not yet so relatively developed themselves. Had Japan done so with regard to patents, it might not have had its strong electronics industry (Mazzoleni \& Nelson 1998). Had the US done so with regard to copyrights, it might not have had its strength in the entertainment industry that it now has. ${ }^{\text {xii }}$

So, what should be done to prevent the system of IPRs from being hijacked by larger firms particularly for strategic purposes? Raising standards for obtaining patents, aligning incentives of patent officers with that of the general interest, and making sure that incentives to initial inventors are more clearly and evenly weighed "against incentives for follow-on innovators" (Barton 2000) is not enough. Narrowing the scope of patents is one option, shortening the duration of (some) patents is another. Differentiating between patents covering different areas has been suggested by Bill Gates. In addition, anti-trust policy should be as zealously pursued at the global level as IPRs are at the moment by such organizations as WIPO and WTO. Such an organization could focus in particular on the effects for technological development in or technology transfer to developing countries.

There are other suggestions. First, to phase in a system where innovation is stimulated by (optionally) rewarding innovators. This system is superior to the IPR system under a range of circumstances (Shavell \& van Ypersele 2001, Wright 1983). Veblen’s spirit of workmanship can be trusted to some extent to produce new and useful technology even without direct monetary reward the application of the idea of open source development proves this case. Direct monetary reward can decrease people's efforts to reach a specific goal as much as it can stimulate them (Le Grand 2003). ${ }^{\text {xii }}$

\section{References:}

Adams, W.J., and Encaoua, D. “Distorting the direction of technological Change.” European Economic Review 38 (1994): 663-73.

Arundel, A. “The relative effectiveness of patents and secrecy for appropriation.” Research Policy 30 (2001): 611-624.

Barton, J.H. “Reforming the Patent System.” Science 287, no. 5460 (2000): 1933-1934.

Baumol, W.J. The free-market innovation machine. Princeton, NJ: Princeton UP, 2002.

Bittlingmayer, G. "Property rights, progress, and the aircraft patent agreement." Journal of Law and Economics 31, no. 1 (1988): 227-248.

Cooke, P. Knowledge Economies. London: Routledge, 2002.

Cowan, R., David, P., and Foray, D. "The explicit economics of knowledge codification and tacitness.” Industrial Change and Corporate Change 9 no. 2 (2000): 211-53. 
Dolfsma, W. “Towards a Dynamic (Schumpeterian) Welfare Theory.” Research Policy 34, no. 1 (2005): 69-82

Dolfsma, W., and Soete, L., eds. Understanding the Dynamics of the Knowledge Economy. Cheltenham: Edward Elgar, 2006.

Dolfsma, W. Knowledge Economies - Innovation, Organization and Location. London: Routledge, 2007.

Foray, D., and Lundvall, B.-A. The Knowledge-Based Economy: From the Economics of Knowledge to the Learning Economy. In Oecd Documents: Employment and Growth in the Knowledge-Based Economy (pp. 11-32). Paris: OECD, 1996.

Gilbert, R.J., and Newbery, D.M.G. "Preemptive Patenting and the Persistence of Monopoly.” American Economic Review 72, no. 3 (1982): 514-526.

Harris, C., and Vickers, J. "Patent Races and the Persistence of Monopoly.” Journal of Industrial Economics 33, no. 4 (1985): 461-481.

Helpman, E. “Innovation, Imitation, and Intellectual Property Rights.” Econometrica 61, no. 6 (1993): 12471280.

Henn, H.G. “The Quest for International Copyright Protection.” Cornell Law Quarterly 43 (1954.

Hettinger, E.C. “Justifying Intellectual Property.” Philosophy and Public Affairs 18, no. 1 (1989): 31-52.

Hubbard , T., and Love, J. “A new framework for global healthcare R\&D.” PLoS Biology 2, no. 2 (2004) : 147150.

Langford, J. “Intellectual Property Rights: technology transfer and resource implication.” American Journal of Agricultural Economics 79, no. 5 (1997): 1576-83.

Lanjouw, J.O., and Schankermann, M. "Protecting intellectual property rights: are small firms handicapped?” Journal of Law and Economics 47 (April 2004): 45-74.

Le Grand, J. Motivation, Agency and Public Policy: Of Knights and Knaves, Pawns and Queens. Oxford: Oxford UP, 2003.

Lemley, M.A., and Shapiro, C. “Probabilistic Patents.” Journal of Economic Perspectives 19, no.2 (2005): 7598.

Lerner, J. "Patenting in the shadow of competitors.” Journal of Law and Economics 38 (1995).

Levin, R., Klevorick, A., Nelson R., and Winter, S. “Appropriating the Returns from Industrial Research and Development.” Brookings Papers on Economic Activity 3 (1987).

Machlup, F. An Economic Review of the Patent System. Washington DC: US Government Printing Office, 1958.

Mansfield, E. “Patents and Innovation: an empirical study.” Management Science 32, no. 2 (1986): 173-181.

Nelson, R.R. “The simple economics of basic scientific research.” Journal of Political Economy 57(1959): 297306.

Mazzoleni, R. and Nelson, R.R. "The benefits and costs of strong patent protection: a contribution to the current debate.” Research Policy 27 (1998): 273-284. 
Oddi, A.S. “The international patent system and third world development: Reality of myth?” Duke Law Journal 5 (November 1987): 831-877.

Organization for Economic Cooperation and Development. Patents and Innovation in the International Context. Paris: OECD 1997.

Perelman, M. “The Political Economy of Intellectual Property.” Monthly Review 54, no. 8 (2003): 29-37.

Post, D. Some Thoughts on the Political Economy of Intellectual Property: A Brief Look at the International Copyright Relations of the United States. Temple University Law School/Cyberspace Law Institute, 1998.

Romer, P. “When should we use intellectual property rights?” American Economic Review 92, no. 2 (2002): 213-6.

Scotchmer, S., and Green, J. "Novelty and disclosure in patent law.” RAND Journal of Economics 21 (1990): 131-146.

Shavell S., and van Ypersele, T. "Rewards versus intellectual property rights." Journal of Law and Economics 44 (October 2001): 525-547.

Takalo T., \& Kanniainen V. "Do patents slow down technological progress? Real options in research, patenting, and market introduction.“ International Journal of Industrial Organization 18 (2000): 1105-27

Towse, R., and Holzhauer, R., eds.,The Economics of Intellectual Property. Cheltenham: Edward Elgar, 4 volumes, 2002.

UNCTAD. World Investment Report. United Nations Conference on Trade and Development, 2005.

Veblen, T. B. "On the nature of capital: Investment, intangible assets, and the pecuniary magnate.” Quarterly Journal of Economics 23, no. 1 (1908): 104-136.

Wright, B.D. "The economics of invention incentives: Patents, prizes, and research contracts.” American Economic Review 73, no. 4 (1983): 691-707.

\footnotetext{
${ }^{\mathrm{i}}$ Intellectual Property Rights include patents (utility, design and plant), copyrights, and trademarks. "Intellectual property rights are the rights given to persons over the creations of their minds.”

${ }^{i i}$ Legal scholars are clear on this as well. Oddi (1987) offers an early discussion on the effects of IPRs on the prospects for development of Third World countries.

iii Some firms, including Merck \& Co, Bristol-Myers Squibb Co, GlaxoSmithKline PLC and Abbott Laboratories have reduced prices in Africa and Brazil for medication against HIV/AIDS. These firms may be genuinely concerned by the toll of this disease for these countries. They may also be concerned about their reputation, as well as by threats to produce generic variants of the drugs after invoking a compulsory license clause. It is likely that these firms are equally keen to prevent parallel import, in breach of stipulations about national exhaustion in IP law. The WTO-TRIPS agreement places significant restrictions on the ability of
} 
developing countries to impose compulsory licenses (Oddi 1987), the bilateral agreements that the US has made with several countries is even more restrictive (Hubbard \& Love 2004). Contrast the discussion about HIV/AIDS drugs with the much more mooted discussion about patents on drugs that prevent or cure anthrax or avian influenza. In the former case the USA threatened to invoke the compulsory license clause against the German manufacturer Bayer who had the patent on the drug to cure anthrax. In the latter case, a larger number of predominantly developed countries are worried about their populations being affected. The Swiss pharmaceutical company Roche owns the patent for and produces Tamiflu.

${ }^{\text {iv }}$ Including establishment of 'prior art', and bio-prospecting.

${ }^{\vee}$ This rationale is founded in John Locke’s argument for property rights in general. In his view, a person's establishes a right of property in that with which she 'mixes her labor', provided that 'enough and as good [is] left in common for others’. The later proviso has, as might be expected, has provoked discussion.

${ }^{v i}$ The product of the mind is part of the self, so to speak. A result of this is that copyrights in a European context include so-called 'moral' rights. These are inalienable, non-transferable. Even when a piece protected under copyright law is sold, the new owner may not alter it without consent of the author.

vii This would hold particularly in the case of patents as they protect the idea itself, and not the particular way in which an idea is expressed as is the case for copyrights, from being used without the permission of and possible payment to the rights holder. Copyright protection does tend to last longer (life of the author plus 70 years) than the protection patents offer: 20 years in most cases.

viii The number of patents granted to developing countries, especially to countries in Asia such as India and China, increases rapidly, albeit from a small base (UNCTAD 2005).

${ }^{\text {ix }}$ From the perspective of a legal scholar Oddi (1987, p.839) has crucially argued that: "Patent statutes do not distinguish, and appear to be incapable of distinguishing, those inventions that are patent induced from those that are nonpatent induced." He holds that far less inventions in developing countries that are patent induced. ${ }^{\mathrm{x}}$ Some of that imitation will result in the creation of new processes and new products, even if only incremental improvements. It is shown that when supply of new innovations is elastic, the best way to induce innovation is through contracts and not through patents. As Wright (1983, p.702) argues: “contracts are best when the research process is most like activities routinely undertaken.” 
${ }^{x i}$ In one of the few studies that can shed some empirical light on this issue, Bittlingmayer (1988) claims that the setting up of a patent pool for the aircraft industry, at the behest of the US government as it was drawn into WWI, certainly ended a paralyzing patent dispute. Bittlingmayer (1988, p.248) found no evidence that this patent pool suppressed innovation and provided consumers with an inferior product. What is significant is that the board overseeing the patent pool would not allow any patent granted by the USPTO to enter the pool. Given that patent stacking is an often used strategy, opening up the possibility of creating a patent pool does decrease the possibility of negotiations breaking down (Levin et al. 1987).

xii The United States did not allow foreigners to obtain copyrights for a long time (Henn 1954). The first US Copyright Act expressly stated that nothing in the Act should be read to "prohibit importation or vending, reprinting, or publishing within the United States of any map, chart, book, or books, written, printed or published by any person not a citizen of the United States, in foreign parts" (Post 1998). A similar situation hold for patent law (Oddi 1987)

xiii Wright (1983, p.704) has shown that contracts, rather than patents, work best to induce innovation when researchers are highly responsive to incentives! 


\section{Publications in the ERIM Report Series Research* in Management}

\section{ERIM Research Program: "Organizing for Performance"}

2006

IPRs, Technological Development, and Economic Development

Wilfred Dolfsma

ERS-2006-004-ORG

Institution Building and Change in China

Barbara Krug and Hans Hendrischke

ERS-2005-008-ORG

* A complete overview of the ERIM Report Series Research in Management: https://ep.eur.nl/handle/1765/1

ERIM Research Programs:

LIS Business Processes, Logistics and Information Systems

ORG Organizing for Performance

MKT Marketing

F\&A Finance and Accounting

STR Strategy and Entrepreneurship 